\title{
Internationalization of Indonesian Traditional Culinary (Case Study: Enrichment Goat Tongseng with Red Wine)
}

\author{
Asep Parantika ${ }^{1}$, Minggus U Marpaung² \\ ${ }^{1,2}$ Sekolah Tinggi pariwisata Sahid, Jakarta, Indonesia \\ Email : ${ }^{1}$ asepparantika@ @stpsahid.ac.id
}

\begin{abstract}
Indonesia is currently in the midst of promoting their nature beauty and culture diversity including its culinary. Despite becoming a soft diplomacy to many countries in the world, this work has an objective to increase the number of foreign tourist coming to Indonesia. Beside Rendang and Fried Rice, Indonesia still have number of Culinary to be promoted, however some consideration is necessary in order to internationalized Indonesian Culinary. Wine as a mixture for food is possible to be added in 'Tongseng' (Goat Sweet Curry Soup) as one of Indonesian famous dish. The purpose of this research is to increase the quality of Tongseng, so it can raise the popularity into the people around the world. The problem discussed is the percentage use of wine toward the quality and consumer's preference about Tongseng. Author used ANOVA and Duncan Test to test hedonic and hedonic quality level which was tested by 20 moderate trained panelists. Then it was found that Tongseng sample with $30 \%$ wine is rated the best.
\end{abstract}

Keywords - Traditional Food, Red wine, Tongseng, Goat, Soup.

\section{INTRODUCTION}

Since 2012, Indonesian government through Ministry of Tourism and Economy Creative has confirmed 30 Icon of Indonesian Traditional Culinary in objective to turn it to be a soft diplomacy to many countries in the world for Indonesia to be well known of its culinary beside the nature beauty and diversity of culture. Rendang and fried rice are the example of popular Indonesian food, however there are 1001 more of Indonesian original dish which are not enough popular. Some aspects are playig part on this, from a complicated step of making the particular dish, limited ingredients to its spiciness which are most of the times not sutable enough for foreign people palate. Some solutions then needed in order to introduce Indonesian Traditional food to International world. One of the solutiom we proposed is to harmonize between International taste with Indonesian taste such as adding wine into Indonesian dish, in this research, the dish choosed is Tongseng.

Wine

Wine is a beverage originaly coming from Mesopotamia region which then spreading to many countries in the world. Wine is a beverage containing alcohol in the range between $8-15 \%$ as a result from grape fermentation. Wine making knowledge known as Oenology and its experts known as Oenologist (Rankine, 1998). Indonesia Ministry of Law in 2012 no.762 declare wine as a result of a whole fermentation from grape or and its mixture. President Decree no.3, 1997 regarding type of Alcoholic Beverage declare that Wine include t type $\mathrm{B}$ which is a beverage consisting alcohol and etanol $(\mathrm{C} 2 \mathrm{H} 5 \mathrm{OH})$ more than $5 \%$ to $20 \%$.

Cooking wine is a method of cooking using wine into the process of making dish. Red Wine normaly uses for 3 objectives such as for marinating, additional ingredients or or accompany the dish. In marinating process, wine is helping meat, chicken or seafood to get tender faster due its acid contains in the wine after the fermentation. In cooking process, wine is giving extra taste to the food. 


\section{Tongseng}

Tongseng is a traditional dish from Central Java. In 18th to 19th Century traders from Middle East were coming to do trading in Indonesia Archipelago. They were spreading religion and their culture including traditional food, consuming meat and Goat/goat. Tongseng made by cooking goat with sweet soya sauce, herbs and spices, and cooked it with Curry sauce. To have some texture, fresh tomato and cabbage is adding. This dish is famous as Tongseng. Klego region, Boyolali, Central Java believe to be the first place resulting Tongseng.

\section{Data \& Method of Research}

Ingredients in Tongseng making process include goat meat, bay leave, water, coconur milk, galangal, lemongrass, cauiflower, spring onion, tomato, shallot, garlic, chili, sweet soya sauce oil, pepper, candlenut, turmeric, ginger and Coriander. Writer adding one type of table wine which is red wine Gerard Bertrand reserve special Merlot 2014 - France.

\section{Problematics}

Based on the background above, the problems conclude for this research are below:

1. Adding wine with different quantity, will it resulting different quality of Tongseng?

2. Is there any differences of sensoric quality (texture, taste, aroma, color) toward Tongseng with red wine quality?

3. Is there any preferences different from the consument towards Tongseng with red wine?

\section{METHODS}

\section{A. Place \& Time of Research}

Research of adding Wine into Tongseng in kitchen of STP Sahid by inviting 20 innternational students (Darmasiswa Program) come from 16 nationality as panelis.

\section{B. Formule of Wine Used}

TABLE 1. INGREDIENT

\begin{tabular}{|c|c|c|c|c|c|}
\hline \multirow{2}{*}{ No } & \multirow{2}{*}{ Ingredient } & A0 & $\mathrm{A} 1$ & $\mathrm{~A} 2$ & A3 \\
\hline & & $0 \%$ & $10 \%$ & $20 \%$ & $30 \%$ \\
\hline 1 & Water & $1000 \mathrm{ml}$ & $1000 \mathrm{ml}$ & $1000 \mathrm{ml}$ & $1000 \mathrm{ml}$ \\
\hline 2 & Coconut Milk & $800 \mathrm{ml}$ & $720 \mathrm{ml}$ & $640 \mathrm{ml}$ & $560 \mathrm{ml}$ \\
\hline 3 & Wine & 0 & $80 \mathrm{ml}$ & $160 \mathrm{ml}$ & $240 \mathrm{ml}$ \\
\hline
\end{tabular}


C. Scheme of Research

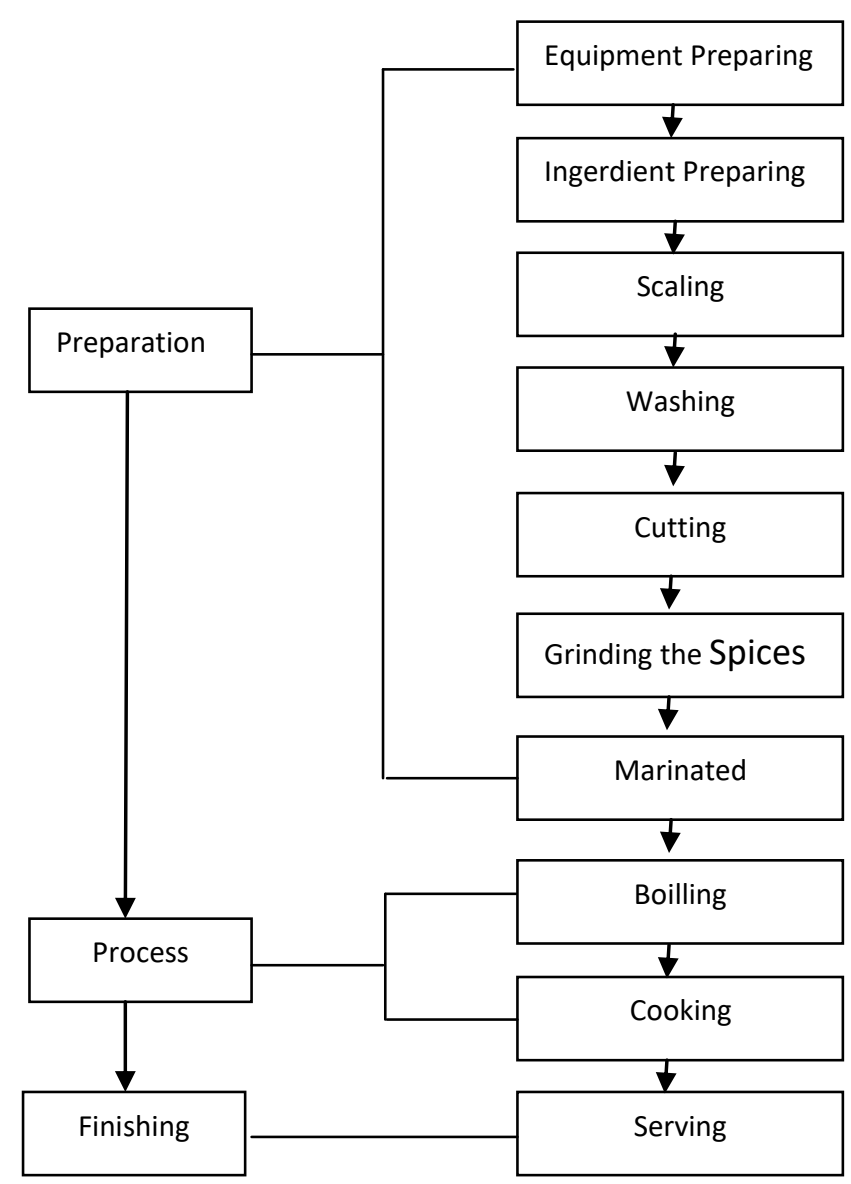

Fig. 1 Scheme Of Research

\section{RESULT AND DISCUSSSION}

This research is using the combination of quantitative and qualitative method which also known as "multi method" (Jonker and Pennink, 2010; Sugiyono, 2007). Qualitative as a result of the process of making Tongseng and Quantitative as a result of sensoric evaluation of the questionnaire from panelis, using the analysis of One Way Anova to find out the impact and criteria toward the expected result (Hamdi \& Bahruddin, 2014) and Duncan Test to match the errors for each range of total group toward the expected act (Sahai \& Ageel, 2012) using SPSS 20.

Sensoric evaluation or organoleptik is a knowledge using human senses to define its texture, appearance, aroma and food flavor. Organoleptik test done to 20 panelis people of non moslem foreign students who favoured Goat dished and wine with two type of test, which are (i) Preference Test (Hedonic Test) such as very like, like, fair, not really like, dislike, hate (ii) Quality Test ( Hedonic Quality Test ) such as good or bad and tender-hard for meat. Each anelis obliged to give scores to Tongseng in hedonic test form. Scoring done by giving a $(\sqrt{ })$ to each parameter available. 


\section{A. Average Result from Hedonic Test}

To know the level of public preference of Tongseng with wine, preference test applied to test the perimeter in terms of color, taste, aroma, and texture. The analysis used in this preference test is OneWay ANOVA (Analysis of Variance) due the testing is done by using each indicator.

TABLE 2. HEDONIC TEST RESULT

\begin{tabular}{lcccc}
\hline \multicolumn{5}{c}{ Hedonic Test } \\
\hline Average parameters & $\begin{array}{c}\text { Sample } \\
0 \%\end{array}$ & $\begin{array}{c}\text { Sample } \\
10 \%\end{array}$ & $\begin{array}{c}\text { Sample } \\
20 \%\end{array}$ & $\begin{array}{c}\text { Sample } \\
30 \%\end{array}$ \\
\hline Collour & 3.45 & 4.25 & 3.85 & 3.60 \\
Taste & 3.20 & 4.00 & 2.25 & 3.85 \\
Flavor & 3.05 & 3.70 & 4.15 & 4.55 \\
Texture & 3.00 & 3.45 & 3.95 & 4.30 \\
Total Average & 3.18 & 3.85 & 4.05 & 4.08 \\
\hline
\end{tabular}

The average result of preference test samples found that a $30 \%$ wine mix is the best sample with a very brown color, very tasting wine, and a creamy and very flavorful meat texture, with a total average of 4.08 .

1) Hedonic Test with colour parameter

TABLE 3. HEDONIC TEST RESULT WITH COLOUR PARAMETER

\begin{tabular}{lcccc}
\hline \multicolumn{5}{c}{ Hedonic Test } \\
\hline \multirow{2}{*}{ Collour Parameters } & Sample & Sample & Sample & Sample \\
Average & $0 \%$ & $10 \%$ & $20 \%$ & $30 \%$ \\
& 3.45 & 4.25 & 3.85 & 3.60
\end{tabular}

From the table. 2 above, the hedonic result is known that the preferred color is a sample of $10 \%$ wine, then the second rank of $20 \%$ wine, and the third rank of $30 \%$ wine.

\section{TABLE 4. DUNCAN COLOR PARAMETER TEST RESULT}

Duncan
\begin{tabular}{|l|r|r|r|}
\hline Produk & \multirow{2}{*}{ N } & \multicolumn{2}{|c|}{ Subset } \\
\cline { 3 - 4 } & & 1 & \multicolumn{1}{|c|}{2} \\
\hline 0 & 20 & 3.4500 & \\
30 & 20 & 3.6000 & \\
20 & 20 & 3.8500 & 3.8500 \\
10 & 20 & & 4.2500 \\
Sig. & & .077 & .063 \\
\hline
\end{tabular}

Means for groups in homogeneous subsets are displayed.

Based on observed means.

The error term is Mean Square(Error) $=.448$.

a. Uses Harmonic Mean Sample Size =

20.000 .

b. Alpha $=.05$. 
Duncan color parameter test results with Alpha 0.05 on Tongseng with red wine sample stated that $0 \%$ sample and $10 \%$ wine there is no real color difference. In the sample $10 \%$ and $20 \%$ wine also there is no real color difference. In the sample $20 \%$ and $30 \%$ of wine there is no real color difference. But in the sample $0 \%, 20 \%$ and $30 \%$ wine there is a real color difference.

2) Hedonic Quality Test Result

TABLE 5. HEDONIC TEST WITH TASTE PARAMETER RESULT

\begin{tabular}{lcccc}
\hline \multicolumn{5}{c}{ Hedonic Test } \\
\hline Taste Parameters & Sample & Sample & Sample & Sample \\
Average & $0 \%$ & $10 \%$ & $20 \%$ & $30 \%$ \\
& 3.20 & 4.00 & 2.25 & 3.85 \\
\hline
\end{tabular}

From the preference test result or hedonic test according to 20 panelists to taste parameter is a sample of $20 \%$ wine, second rank is $10 \%$ wine, and third rank is $30 \%$ wine

\section{TABLE 6. HEDONIC TEST RESULT WITH TASTE PARAMETER}

Duncan
\begin{tabular}{|l|r|r|r|}
\hline Produk & \multirow{2}{*}{$N$} & \multicolumn{2}{|c|}{ Subset } \\
\cline { 3 - 4 } & & 1 & \multicolumn{1}{|c|}{2} \\
\hline 0 & 20 & 3.2000 & \\
30 & 21 & & 3.8571 \\
10 & 20 & & 4.0000 \\
20 & 19 & & 4.2632 \\
Sig. & & 1.000 & .079 \\
\hline
\end{tabular}

Means for groups in homogeneous subsets are displayed.

Based on observed means.

The error term is Mean Square(Error) $=.467$.

a. Uses Harmonic Mean Sample Size =

20.000

b. Alpha $=.05$.

Duncan test result to texture parameter with Alpha 0,05 on sample of Goat Tongseng with wine stated that sample $0 \%$ and $10 \%$ wine there is no real texture difference, but there is real texture difference with sample 20 and $30 \%$ wine.

3) Hedonic Test with aroma parameter

TABLE 7. HEDONIC TEST RESULT WITH FLAVOR PARAMETER

\begin{tabular}{lcccc}
\hline \multicolumn{5}{c}{ Hedonic Test } \\
\hline Taste Parameters & Sample & Sample & Sample & Sample \\
Average & $0 \%$ & $10 \%$ & $20 \%$ & $30 \%$ \\
& 3.05 & 3.70 & 4.15 & 4.55 \\
\hline
\end{tabular}

The preferrence test result or hedonic test is known that according to 20 panelists the preferred aroma parameters are $30 \%$ wine sample, the second rank is $20 \%$ wine, and the third rank is $10 \%$ wine. 
TABLE 8. DUNCAN HEDONIC TEST RESULT WITH AROMA PARAMETER

Duncan
\begin{tabular}{|l|r|r|r|r|r|}
\hline produk & \multirow{2}{*}{$N$} & \multicolumn{4}{|c|}{ Subset } \\
\cline { 3 - 6 } & & 1 & 2 & 3 & 4 \\
\hline 0 & 20 & 3.0500 & & & \\
10 & 20 & & 3.7000 & & \\
20 & 20 & & & 4.1500 & \\
30 & 20 & & & & 4.5500 \\
Sig. & & 1.000 & 1.000 & 1.000 & 1.000 \\
\hline
\end{tabular}

Means for groups in homogeneous subsets are displayed.

Based on observed means.

The error term is Mean Square(Error) $=.272$.

a. Uses Harmonic Mean Sample Size $=20.000$

b. Alpha $=.05$.

Duncan test results aroma parameters with Alpha 0.05 in Tongseng with wine stated a significant difference of aroma between control sample of $0 \%, 10 \%, 20 \%$ and $30 \%$ wine.

4) Hedonic Test with texture parameter

TABLE 9. HEDONIC TEST RESULT WITH TEXTURE PARAMETER

\begin{tabular}{lcccc}
\hline \multicolumn{5}{c}{ Hedonic Test } \\
\hline Taste Parameters & Sample & Sample & Sample & Sample \\
\multirow{2}{*}{ Average } & $0 \%$ & $10 \%$ & $20 \%$ & $30 \%$ \\
& 3.00 & 3.45 & 3.95 & 4.30 \\
\hline
\end{tabular}

The preference test result or hedonic test stated that according to 20 panelists on the preferred texture parameters are $30 \%$ wine samples, the second rank is $20 \%$ wine, and the third rank is $10 \%$ wine.

TABLE 10. DUNCAN HEDONIC TEST RESULT WITH TEXTURE PARAMETER

Duncan
\begin{tabular}{|l|r|r|r|r|}
\hline produk & \multirow{2}{*}{$\mathrm{N}$} & \multicolumn{3}{|c|}{ Subset } \\
\cline { 3 - 5 } & & 1 & 2 & 3 \\
\hline 0 & 20 & 3.0000 & & \\
10 & 20 & & 3.4500 & \\
20 & 20 & & & 3.9500 \\
30 & 20 & & & 4.3000 \\
Sig. & & 1.000 & 1.000 & .073 \\
\hline
\end{tabular}

Means for groups in homogeneous subsets are displayed Based on observed means

The error term is Mean Square(Error) $=.370$.

a. Uses Harmonic Mean Sample Size $=20.000$

b. Alpha $=.05$.

Duncan test results with aroma parameters in Alpha 0.05 in Tongseng with wine stated that there is a significant difference of aroma between control sample $0 \%, 10 \%, 20 \%$ and $30 \%$ wine. 
B. Hedonic Quality Test Result

Quality test or hedonic test done to determine the quality difference from each sampel. Hedonic test done from 20 trained panelist

TABLE 11. HEDONIC QUALITY RESULT

\begin{tabular}{lcccc}
\hline \multicolumn{5}{c}{ HEDONIC TEST } \\
\hline Average Parameters & Sample & Sample & Sample & Sample \\
Collour & $0 \%$ & $10 \%$ & $20 \%$ & $30 \%$ \\
Taste & 4.00 & 3.00 & 2.25 & 4.30 \\
Flavour & 1.00 & 2.10 & 2.70 & 3.55 \\
Texture & 1.00 & 2.00 & 2.75 & 3.45 \\
Average & 1.75 & 2.35 & 2.90 & 3.10 \\
& 1.94 & 2.36 & 2.65 & 2.89 \\
\hline
\end{tabular}

The average result of the entire hedonic quality test sample stated that the $30 \%$ wine mix is the best sample with very brown color, very strong taste of wine, and the texture of the meat is soft and aromatic. This is caused by the total value of the largest obtained among the other substitutes with a total average of 2.89 .

1) Hedonic Test with Color Parameter

TABLE 12. HEDONIC TEST RESULT WITH COLOR PARAMETER

\begin{tabular}{lcccc}
\hline \multicolumn{5}{c}{ HEDONIC TEST } \\
\hline Average Parameters & Sample & Sample & Sample & Sample \\
Collour & $0 \%$ & $10 \%$ & $20 \%$ & $30 \%$ \\
& 4.00 & 3.00 & 2.25 & 4.30 \\
\hline
\end{tabular}

From the result of quality test or hedonic quality test, stated that according to 20 panelists trained, the preferred color parameters are with $10 \%$ wine samples with slightly dark brown criteria, the second rank is $20 \%$ wine, and third rank is $30 \%$ wine.

TABLE 13. DUNCAN HEDONIC TEST RESULT WITH COLOR PARAMETER

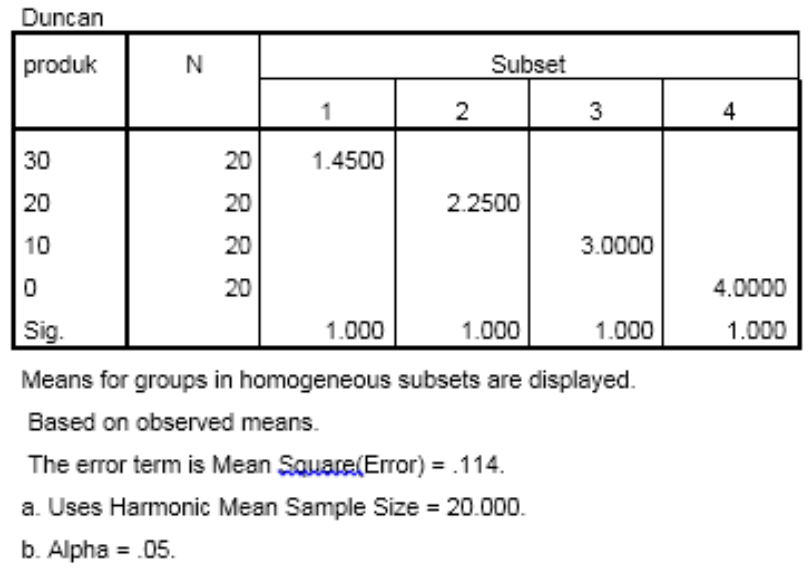


Duncan color parameter test results with Alpha 0.05 in Tongseng samples with wine stated that samples $0 \%, 10 \%, 20 \%$ and $30 \%$ wine shows real color differences in hedonic quality test.

2) Hedonic Test with taste Parameter

TABLE 14. HEDONIC TEST RESULT WITH TASTE PARAMETER

\begin{tabular}{lcccc}
\hline \multicolumn{5}{c}{ HEDONIC TEST } \\
\hline \multirow{2}{*}{ Average Parameters } & Sample & Sample & Sample & Sample \\
\multirow{2}{*}{ Taste } & $0 \%$ & $10 \%$ & $20 \%$ & $30 \%$ \\
& 1.00 & 2.10 & 2.70 & 3.55 \\
\hline
\end{tabular}

From the result of quality test or hedonic quality test, stated that according to 20 panelists trained, the preferred taste parameter is with sample of $30 \%$ wine with highly tasty criteria of wine, then the second rank is $20 \%$ wine, and third rank is $10 \%$ of wine.

TABLE 15. DUNCAN HEDONIC TEST RESULT WITH TASTE PARAMETER

\begin{tabular}{|c|c|c|c|c|c|}
\hline \multirow[t]{2}{*}{ produk } & \multirow[t]{2}{*}{$\mathrm{N}$} & \multicolumn{4}{|c|}{ Subset } \\
\hline & & 1 & 2 & 3 & 4 \\
\hline 0 & 20 & 1.0000 & & & \\
\hline 10 & 20 & & 2.1000 & & \\
\hline 20 & 20 & & & 2.7000 & \\
\hline 30 & 20 & & & & 3.5500 \\
\hline Sig. & & 1.000 & 1.000 & 1.000 & 1.000 \\
\hline \multicolumn{6}{|c|}{ Means for groups in homogeneous subsets are displayed. } \\
\hline \multicolumn{6}{|c|}{ Based on observed means. } \\
\hline \multicolumn{6}{|c|}{ The error term is Mean Square(Error) $=.170$. } \\
\hline \multicolumn{6}{|c|}{ a. Uses Harmonic Mean Sample Size $=20.000$. } \\
\hline \multicolumn{6}{|c|}{ b. Alpha $=.05$} \\
\hline
\end{tabular}

Duncan test with color parameter results with Alpha 0.05 in Tongseng samples with wine stated that $0 \%, 10 \%, 20 \%$ and $30 \%$ wine samples shown real color difference.

3) Hedonic Test with Texture parameter

TABLE 16. HEDONIC TEST RESULT WITH TEXTURE PARAMETER

\begin{tabular}{lcccc}
\hline \multicolumn{5}{c}{ HEDONIC TEST } \\
\hline \multirow{2}{*}{ Average Parameters } & Sample & Sample & Sample & Sample \\
Texture & $0 \%$ & $10 \%$ & $20 \%$ & $30 \%$ \\
& 1.75 & 2.35 & 2.90 & 3.10 \\
\hline
\end{tabular}

From the result of quality test or hedonic quality test, stated that according to 20 panelists trained, the preferred texture parameters are samples with $30 \%$ wine showing soft meat criteria, the second rank is $20 \%$ wine, and third rank is $10 \%$ wine 
TABLE 17. DUNCAN HEDONIC TEST RESULT WITH TEXTURE PARAMETER

Duncan
\begin{tabular}{|l|r|r|c|c|}
\hline Produk & \multirow{2}{*}{$N$} & \multicolumn{3}{|c|}{ Subset } \\
\cline { 3 - 5 } & & 1 & 2 & 3 \\
\hline 0 & 20 & 1.7500 & & \\
10 & 20 & & 2.3500 & \\
20 & 20 & & & 2.9000 \\
30 & 20 & & & 3.1000 \\
Sig. & & 1.000 & 1.000 & .143 \\
\hline
\end{tabular}

Means for groups in homogeneous subsets are displayed. Based on observed means

The error term is Mean Square(Error) $=.183$.

a. Uses Harmonic Mean Sample Size $=20.000$

b. Alpha $=.05$

The Duncan test with texture parameter in Alpha 0.05 in Tongseng samples with wine stated that $30 \%$ samples, and in $20 \%$ wine shown no real texture difference, somehow a significant texture difference appeared compared to $10 \%$ and $0 \%$ wine samples.

4) Hedonic Test with aroma parameter

TABLE 18. HEDONIC TEST RESULT WITH FLAVOUR PARAMETER

\begin{tabular}{lcccc}
\hline \multicolumn{5}{c}{ HEDONIC TEST } \\
\hline Average Parameters & Sample & Sample & Sample & Sample \\
Flavour & $0 \%$ & $10 \%$ & $20 \%$ & $30 \%$ \\
& 1.00 & 2.00 & 2.75 & 3.45 \\
\hline
\end{tabular}

From the result of quality test or hedonic quality test, stated that according to 20 panelists trained, the preferred aroma parameters are shown in $30 \%$ wine samples with very scented wine criteria, then the second rank is $20 \%$ wine, and the third rank is $10 \%$ wine.

TABLE 19. DUNCAN HEDONIC TEST RESULT WITH AROMA PARAMETER

Duncan
\begin{tabular}{|l|r|r|r|r|r|}
\hline produk & \multirow{2}{*}{$N$} & \multicolumn{4}{|c|}{ Subset } \\
\cline { 3 - 6 } & & 1 & 2 & 3 & 4 \\
\hline 0 & 20 & 1.0000 & & & \\
10 & 20 & & 2.0000 & & \\
20 & 20 & & & 2.7500 & \\
30 & 20 & & & & 3.4500 \\
Sig. & & 1.000 & 1.000 & 1.000 & 1.000 \\
\hline
\end{tabular}

Means for groups in homogeneous subsets are displayed.

Based on observed means.

The error term is Mean Square(Error) $=.141$.

a. Uses Harmonic Mean Sample Size $=20.000$

b. Alpha $=.05$. 
Duncan test results aroma parameters with Alpha 0.05 in Tongseng with wine sample stated that samples with $0 \%, 10 \%, 20 \%$ and $30 \%$ wine has a real wine flavor difference.

\section{CONCLUSION \& RECOMMENDATION}

Based on research outcome and study, the conclusion are:

a. Wine could become one of ingredients of Goat Tongseng, therefore it practically enhance the quality and aroma. The application of red wine will be better in certain amount, because it can transform the flavour and scent of the dishes as well as increasing the production cost.

b. There's influence in the wine application in different percentage of amount such as $10 \%, 20 \%$, and $30 \%$ impact the Tongseng sensor quality look by the colour, flavour, aroma, and texture. Control product has bright brown colour, no wine flavour, no wine aroma, and meat not soft. The $10 \%$ product has light dark brown colour, hint of wine aroma, and slightly tender meat. The $20 \%$ product has dark brown colour, noticeable wine scent and flavour also tender meat texture. The $30 \%$ product has thick dark brown colour, strong wine scent and flavour as well as really tender texture of meat.

c. Tongseng with $30 \%$ of wine rated as the best proportion from all preference aspects of all samples

Based on the research results the recommendations are below:

a. Tongseng with $30 \%$ of wine can be socialize to public and food industry by its high score from hedonic test/preference test.

b. Following similar research is necessary for Tongseng with red wine mixture of other type in objective to make Tongseng becoming a competitive dish

c. Following similar research using any kind Indonesian Traditional Culinary with other type of Red wine as a mixture in objective to Internationalized Indonesian dishes

\section{REFERENCES}

(1998). Manfaat daging domba dan kambing. Kanisius. Yogyakarta. (2013), Produksi Kelapa Menurut Propinsi di Indonesia. Direktorat Jenderal Perkebunan.

Cahyono B. (2005). Seri budidaya daun bawang. kanisius. Yogyakarta

Canene-Adams K., et al (2004). The growth of the Dunning R3327-H transplantable prostate adenocarcinoma in rats fed diets containing tomato,broccoli, lycopene, or receiving finasteride treatment. FASEB J. 18:A886 (591.4).

Direktorat Jendral Hortikultura Kementrian Pertanian (2015) Statistik Produksi Holtikultura tahun 2014. Jakarta.

Direktorat Jendral P.P.(2012). Pengendalian dan Pengawasan Industri Minuman Beralkohol. Jakarta. Ditjenpp.

Departemen Kesehatan R.I., (1959). Daftar Komposisi Kimia Bahan Makanan. Bahatara Karya Aksara, Jakarta.

Hamdi, A. S, Bahruddin, E (2014). Metode Penelitian Kuantitatif Aplikasi dalam Pendidikan. Yogyakarta: Deepublish.

Handoyo, Yohan (2007). Rahasia Wine.Jakarta: Gramedia.

Kartika, Unoviana (2016)."Serba-serbi Masak Tongseng Enak untuk Sajian Idul Adha". Liputan 6, 04 Sep 2016.

Kaulan Arif,Rizky dan Luluk (2009). Fermentasi Wine.Surakarta.Fakultas Pertanian

Kasmidjo, R.B. (1990) Tempe: Mikrobiologi dan Biokimia Pengolahan serta Pemanfaatannya. Yogyakarta: PAU Pangan dan Gizi.

Koswara, Sutrisno. (2006). Pengujian Organoleptik (Evaluasi Sensori) Dalam Industri Pangan. eBookPangan.com. 
Parantika. A (2015) Le Tourisme Domestique Indonésien: Entre Transfert Et Innovation, Vers Un Nouveau Modèle? Universite d'Angers- France

Parantika. A, Chevalier S.P (2015) "Le Tourisme comme expérience “. In Interdisciplinaires sur le vécu touristique, Presses de l'université du Québec

Parantika. A, Isnaen A.B (2016) "Development of Education Tourism In South Tangerang Region (Case Study: Kandank Jurank Doank)" in Journal of Business on Hospitality and Tourism

Parantika. A, Natalia L (2016) "Wine Club a New Phenomenon of Urban Lifestyle" in Jakarta Proceedings of the Asia Tourism Forum 2016 - the 12th Biennial Conference of Hospitality and Tourism Industry in Asia

Pawignya H. (2010). Minuman Beralkohol. Gramedia Pustaka Utama, Jakarta.

Rahardi, F.(2017)."Minuman Keras". KOMPAS, 25 Feb 2017

Rudi H. (2008). Alcoholic Beverages. http://www.maine.gov/dafs/bablo/ alcohol_bev. Tanggal akses: $18 / 03 / 2013$

Sahai. H., \& Ageel. M. I. (2012). The Analysis of Variance: Fixed, Random and Mixed Models. Springer Science \& Business Media. New York.

Slamet, D.S. (1978). The nutrients and amino acids contents of kecap. Dalam

Situmorang et. al. (2010). Analisis Data: Untuk Riset dan Manajemen Bisnis. USU Press.Medan

Supratman, Stefani.(2015). "Mengenal 5 Tahap Pembuatan Wine" Liputan 6, 07 Nov 2015.

Suriani, N. (2011). Bawang Bawa Untung. Budidaya Bawang Merah dan Bawang Merah. Cahaya Atma Pustaka. Yogjakarta. 